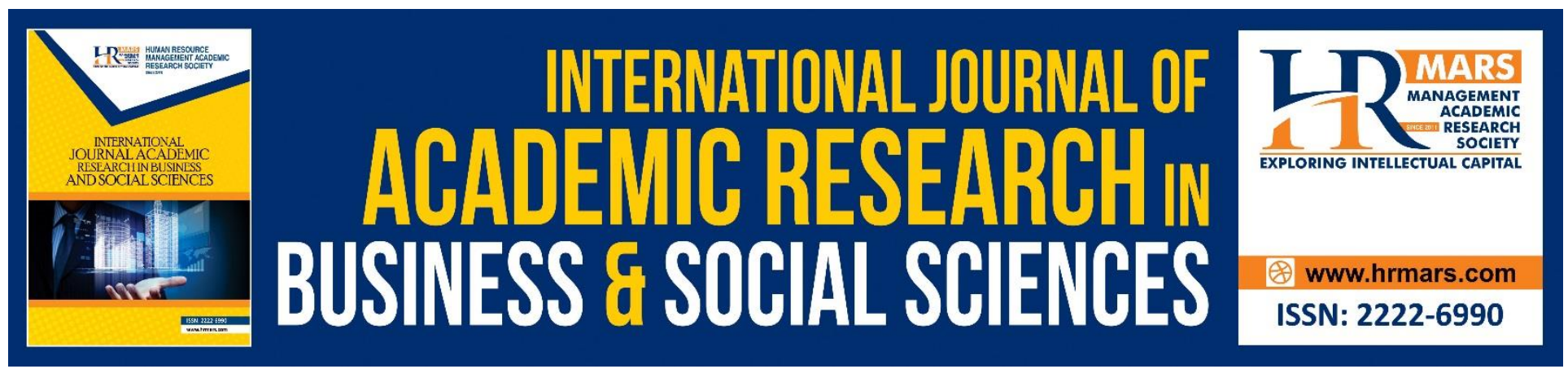

\title{
Analysis Factors Influencing Financial Management Behaviour
}

M. Rizky Dwi Prihartono, Nadia Asandimitra

To Link this Article: http://dx.doi.org/10.6007/IJARBSS/v8-i8/4471

DOI: $\quad 10.6007 /$ IJARBSS/v8-i8/4471

Received: 19 July 2018, Revised: 07 August 2018, Accepted: 23 August 2018

Published Online: 31 August 2018

In-Text Citation: (Prihartono \& Asandimitra, 2018)

To Cite this Article: Prihartono, M. R. D., \& Asandimitra, N. (2018). Analysis Factors Influencing Financial Management Behaviour. International Journal of Academic Research in Business and Social Sciences, 8(8), 308-326.

Copyright: (C) 2018 The Author(s)

Published by Human Resource Management Academic Research Society (www.hrmars.com)

This article is published under the Creative Commons Attribution (CC BY 4.0) license. Anyone may reproduce, distribute, translate and create derivative works of this article (for both commercial and non-commercial purposes), subject to full attribution to the original publication and authors. The full terms of this license may be seen at: $\underline{\text { http://creativecommons.org/licences/by/4.0/legalcode }}$

Vol. 8, No. 8, August 2018, Pg. 308 - 326

Full Terms \& Conditions of access and use can be found at http://hrmars.com/index.php/pages/detail/publication-ethics 


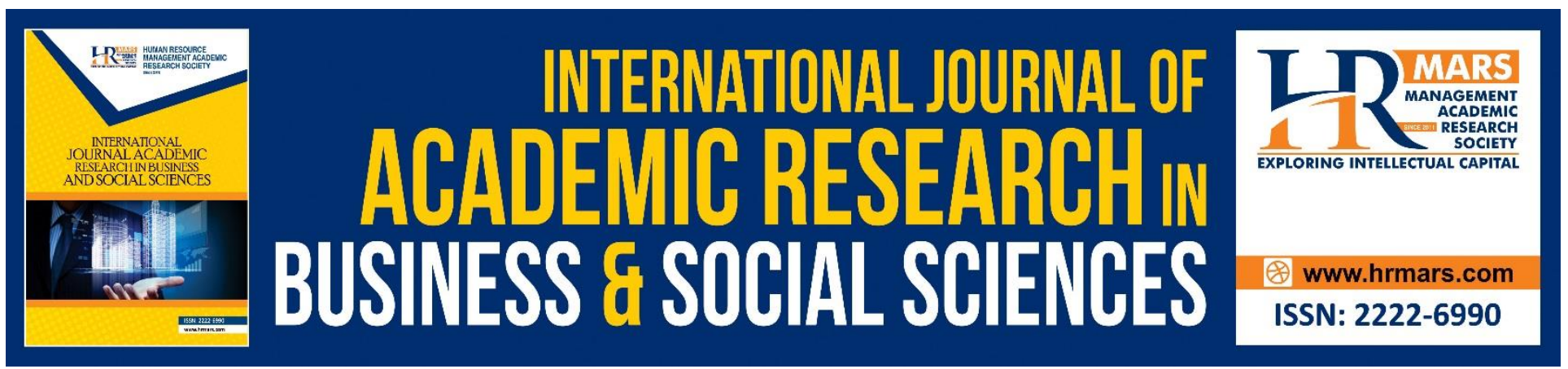

\title{
Analysis Factors Influencing Financial Management Behaviour
}

\author{
M. Rizky Dwi Prihartono \\ Department of Management, Faculty of Economics, Universitas Negeri Surabaya, Indonesia \\ Email: mprihartono@mhs.unesa.ac.id \\ Nadia Asandimitra \\ Department of Management, Faculty of Economics, Universitas Negeri Surabaya, Indonesia \\ Email: nadiaharyono@unesa.ac.id (Corresponding Author)
}

\begin{abstract}
This study aims to examine the effect of income, higher education learning, financial knowledge, financial literacy, financial attitude, and the locus of control toward financial management behavior on Economics Faculty students. The population are 264 respondents that is selected by judgmental sampling. The characteristics of respondents are Economics Faculty students who has taken at least two semesters during the lecture.

The analysis technique used by the researcher is multiple regression analysis. The results show that income effects on financial management behavior. Higher Education learning has no effect on financial management behavior. Financial knowledge has no effect on financial management behavior. Financial literacy effects on financial management behavior. Financial attitude effects on financial management behavior. Locus of control has no effect on financial management behavior. Keywords: Financial Management Behavior, Financial Attitude, Locus Of Control
\end{abstract}

\section{Introduction}

Financial sector independence becomes one of the concentrations for the nation's economic progress solution (Mukeri, 2010). Financial management behavior has become an important factor in improving the welfare of life. Kholilah and Iramani (2013) financial management behavior is the ability of individuals to play the finance role (planning, control, search, and storage) in the long and short term. Implementation of the appropriate pattern of financial management should be supported by an understanding of good financial science and be able to apply in everyday life. Therefore, every student should apply a good pattern of financial behavior in order to start learning the first step to make life prosperous.

On tackling the challenges of financial independence require financial skill factors, financial skills that each individual needs to face global financial challenges such as having income, implementing college finance learning, be able to balance income with expenditure, understanding the types of activities finance, be able to respond to finances by self-control of financial expenditure, 
INTERNATIONAL JOURNAL OF ACADEMIC RESEARCH IN BUSINESS AND SOCIAL SCIENCES

Vol. 8, No. 8, August 2018, E-ISSN: 2222-6990 @ 2018 HRMARS

and can manage personal finances.

Ida and Dwinta (2010) in their study stated that income has no effect on financial management behavior due to the difference between income with own hard work will be different with income earned from others as obtained from family especially their parent. Different from the results of research conducted by Andrew and Linawati (2014) states that one of the demographic factors that income significantly influence the individual financial behavior due to the higher individual's income the wiser in behaving towards the use of finance than someone who has lower incomes. Regardless of the income that someone has if they are not able to manage finances well then personal finance problems will occur.

In the research of Anita and Sari (2015) states that college learning proved to have a significant positive influence on financial management behavior means that the higher learning on collage especially financial knowledge will improve student's financial behavior better. But contrary result result from Asandimitra and Kautsar (2017) age has negatively significant impact on the success of SMEs management by women entrepreneurs in East Java. It happens because the age of women entrepreneurs is dominated by youth. It shows that the younger women entrepreneurs, the more success managing the SMEs. This phenomena caused by high innovation and creativity possessed by youth, which lead them to have more power to develop their business. This is not in line with the results of Herawati research (2015) states that the contribution of college learning proved not to have a significant effect on financial management behavior, because that teaching subjects related to financial management include the company's financial.

Thi et al. (2015) in his research states that financial knowledge has a significant positive effect on financial management behavior because the role of education with the seminars of financial knowledge will increase insight about financial management behavior. While Listiani's findings (2017) state that financial knowledge has no significant effect means that a person has financial knowledge but not practiced in a good financial management behavior.

In the research of Sabri and Falahati (2012) states that financial literacy has a significant effect on financial management behavior. Sina (2016: 94) reveals the condition in which individuals with limited financial condition, but able to leverage and run an understanding of financial literacy in everyday life, it can perform the implementation of financial management now and future so that individuals are not experiencing financial management problems. There are findings from Borden, Lee, Serido, and Collins (2008) after attending a seminar on financial literacy, students reported an increase in restricting the use of credit cards in order to manage finances in a more useful way. Unlike Nidar and Bestari (2012), however, the students' financial literacy tends to be in the low category.

Anthony et al. (2011) states that the financial attitude has a significant negative effect means someone have a good financial management attitude but bad in financial practice. In contrast to Listiani's (2017) research, it is stated that financial attitude has a significant positive effect on financial management behavior, meaning that the more individuals able to apply a good financial attitude, it also has a good effect on the management of personal finance. This is due to the quality of the financial attitude derived from the quality of good education of a person and able to apply in everyday life. The results of Anthony et al. (2011) and Listiani (2017) researched are not in line with the findings of Maharani (2016) revealed that the financial attitude cannot affect financial management behavior.

Research of Ida and Dwinta (2010) states that the locus of control has no significant effect on financial management behavior. This is inversely related to Thi et al. (2015) by arguing that the locus of control has a significant negative effect on financial management behavior, meaning that 
INTERNATIONAL JOURNAL OF ACADEMIC RESEARCH IN BUSINESS AND SOCIAL SCIENCES Vol. 8, No. 8, August 2018, E-ISSN: 2222-6990 @ 2018 HRMARS

someone with good locus of control tends not to apply good financial management behavior. Unlike the Listiani (2017) the better locus of control a person the better pattern of financial management behavior is caused by internal locus of control is more important because individuals who still earn income from other people (the parents) then the individual will be more careful, careful and control its expenditure in accordance with the needs so as not spend money on every month and can be said that the locus of control have a significant positive effect on financial management behavior.

Ansong and Gyensare (2012) finds that students, especially economics majors, tend to have a broader knowledge of finance compared to other majors. In the current condition at the State University of Surabaya, especially the Faculty of Economics has a Vision that is "Becoming a Superior Faculty In the Field of Education and Economic Sciences in accordance with the Demands of Globalization". One of the efforts is to realize the Vision of all campus elements especially Faculty of Economics State University of Surabaya trying maximally by improving the science of economics and foster entrepreneurship spirit. Including all elements of Faculty of Economics State University of Surabaya is an intermediary on helping immedietly realizing this by fostering good financial independence for students.

Researchers look for the phenomenon by using preliminary survey through questionnaire technique which was distributed directly to the respondents involving 30 students from Faculty of Economics, State University of Surabaya, Faculty of Economics and Business Universitas Airlangga, and Faculty of Economics and Business of National Development University (UPN). This preliminary questionnaire uses indicators of statements relating to financial behavior of previous researchers (Nababan and Sadalia, 2012) which have been adjusted as follows: I always pay bills on time (eg paying rent, paying debt to a friend), I always make budget expenditure plan every day, I always do budget expenditure according to daily requirement, I always record expense budget every day, I always set aside fund for expense unexpectedly every day, I always save money every day, I always compare price between sellers. Determination of the number of samples in this preliminary study based on Sekaran (2006) in general, in a study to determine the correlation of the minimum sample size to obtain good results by 30 respondents. Therefore the researchers determined the sample for this preliminary study of 30 respondents at each university taken randomly.

Table 1. Result Preliminary Study

\begin{tabular}{|l|l|c|}
\hline No & University Name & Result(Mean) \\
\hline 1 & State University Of Surabaya & 2.46 \\
\hline 2 & Airlangga University & 2.38 \\
\hline 3 & National Development University & 2.74 \\
\hline \multicolumn{2}{|l}{ Total } & 100 \\
\hline
\end{tabular}

Source: data processed by author (2018)

The researcher conducted a preliminary study to several students of Economics Faculty, State University of Surabaya, Faculty of Economics and Business of University of Airlangga, and Faculty of Economics and Business of National Development University (UPN). It is found the reality that on the field condition many students of Faculty of Economics Universitas Surabaya, Faculty of Economics and Business Universitas Airlangga tend to have difficulty in managing personal finance.

Financial problems will not arise if students do the habit once or twice a month, if done more than it is very likely to experience problems in financial management because the income earned from parents in each month will be spent faster so that asking for remittances back to his parents. 
INTERNATIONAL JOURNAL OF ACADEMIC RESEARCH IN BUSINESS AND SOCIAL SCIENCES

Vol. 8, No. 8, August 2018, E-ISSN: 2222-6990 @ 2018 HRMARS

With such bad behavior that affect student financial management problems. With these conditions researchers want to conduct research on the behavior of financial management of students of Faculty of Economics.

\section{Literature Review}

Income

According to Suroto (2000) income has a meaning as a source of individuals income in meeting their daily needs is considered very important in the life of individuals directly or indirectly. According to Niswonger (2006: 56) suggests definition of Income as the increase in gross profit (gross) owners of capital obtained from the sale of traded goods, service activities expected consumer, lease assets, lending money, and all activities of business operations in earnings maximum. According to Prakoso (2013) income means the total amount of goods and services that can meet the standard of living of the people, that is to say, having income owned by each individual can be said as income per capita of the population, one function of income per capita can be a benchmark of progress or development economy.

According to Wild (2003: 311 ) suggests the definition of income is a maximum value that a person can consume in a period that expects the same state at the end as early as the period. According to Gregory (2003) a person's income is any kind of income source earned by a community or a person in a country, this income can be obtained from bank interest given, dividends or subsidies, and the payment of government payments to the community.

From some definition of income according to some expert experts in the field above, it can be concluded income is a source of person income generated from business operations, services, giving from others (parents) expected maximum value at the beginning of the period equal to the maximum value at the end periods that serve as the fulfillment of the standard of living. According to Ida and Dwinta (2010) classify the amount of income consisting of: the amount of income $\leq R p 1,000,000$, the

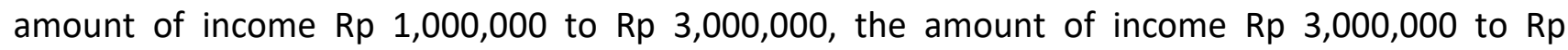
$5,000,000$, and the amount of income $\geq \operatorname{Rp} 5.000 .000$.

\section{Higher Education Learning}

According to Trianto (2009) discloses that learning is a conscious effort of educators to teach their students (giving interaction in learning with various other learning references) to help determine the success of objectives as expected.

Kholilah and Iramani (2013) reveal through the sources of learning methods, media, instructional reference, is expected to provide sufficient supplies to students in understanding science in the field of finance, so students are able to run a life routine realted to financial behavior in the future.

From some definition of college learning according to some expert experts above, it can be concluded college learning is a process of someone learning which transferred by educators with other learning methods in providing an understanding of financial knowledge in the hope that students are able to implement good financial management. Depdiknas (2003) Issuing the formulation of the Law on National Education System in point 11 on formal education is a structured and tiered education consisting of basic education, secondary education, and higher education. 
INTERNATIONAL JOURNAL OF ACADEMIC RESEARCH IN BUSINESS AND SOCIAL SCIENCES

Vol. 8, No. 8, August 2018, E-ISSN: 2222-6990 @ 2018 HRMARS

\section{Financial Knowledge}

According Lusardi and Mitchell (2007) stated that financial knowledge as an insight into finance and then implement in daily life (knowledge and ability). As known the importance of having financial knowledge into one of the efforts in obtaining the welfare of life in the future that is realized from behaving in accordance with the understanding of the financial. According Hilgert et al (2003) financial knowledge is part of the conceptual definition of financial literacy means that financial knowledge with financial literacy has a little different understanding but has the same goal meaning. Financial knowledge has a meaning to give a broad understanding of finance, while financial literacy has a meaning where someone already has an understanding of finance as well as able to understand and run financial activities. Financial knowledge has its own scope including understanding of personal finance, corporate finance, banking, investment, and insurance and so on.

According to Garman, E. Thomas, and Eckert (1985) financial knowledge required the development of financial skills and financial tools to form a chart and a pattern in personal financial management decision making such as choosing a check, credit card or debit card). Development of financial skills and financial tools required by a person to be able to choose the required checks, able to use debit and credit cards wisely so as not to experience financial management problems.

According to Keller, Staelin, Lee, and Hogarth (1987) there are several sources to obtain knowledge about finance through formal education such as college courses, seminars on finance and additional hours of outside school tutoring, as well as through various informal parents, peers and coworkers.

From several definitions of financial knowledge according to the experts above, it can be concluded financial knowledge is an understanding of economics related to financial understanding obtained through formal education such as school, lectures, seminars on finance or additional learning guidance is expected to be able in forming financial skills and financial tools that can implement financial management effectively and efficiently for the sake of the creation of life welfare.

The financial knowledge in this study focuses on a broad understanding of the financial knowledge gained from formal education and lectures of students who tend to discuss about the understanding of corporate finance, banking, and investment with the aim to find out how effective the knowledge received from learning lectures for students. According to Ida and Dwinta (2010) there are five indicators to measure financial knowledge: The terms Interest rates, finance charges, and credit, credit ratings and credit files, manage finances, invest money, what's on your credit report.

\section{Financial Literacy}

According to Chen and Volpe (1998) financial literacy as financial knowledge in financial management, with the definition of the individual's ability to emphasize the ability to understand the initial concept of economics related to finance, how to do its application well. There is a great deal of financial understanding of finances both personally, corporate finance, banking finance, investment finance, insurance finance. The financial literacy of this researcher is more to understanding of personal finance because it has different characteristics between private financial literacy and corporate finance, banking, investment, insurance.

According to Mason and Wilson (2000) argued that financial literacy is the ability of individuals in understanding, obtaining, and evaluating any information that feels relevant in making decisions by understanding the financial risks that result. 
INTERNATIONAL JOURNAL OF ACADEMIC RESEARCH IN BUSINESS AND SOCIAL SCIENCES

Vol. 8, No. 8, August 2018, E-ISSN: 2222-6990 @ 2018 HRMARS

According to Sina (2016: 94) argued that the definition of financial literacy is the ability of individuals in reading, analyzing, and managing, as well as telling the financial condition.

Mahdzan and Tabiani (2013) revealed that to improve financial literacy in financial decision making that is starting from making a mature planning and able to manage every behavior patterns of financial decision making in life such as making a home purchase and plan finance in retirement. According to Shim, Barber, Card, Xiao, and Serido (2010) find out the existence of various important factors that can influence the financial literacy those are social environment, family learning behavior, financial education pursued, the experience of someone in using finance.

From various definitions of financial literacy according to some experts above, it can be concluded that financial literacy is an economic science learning that includes how to get money, understand, evaluate all information before acting in financial decision making by doing the planning and able to manage finances well which can be influenced by the social environment, family education, the experience of others in the use of finance. According to Chen and Volpe (1998) there are four dimensions of financial literacy: Personal Finance/Consumsion, savings, insurance, and investments.

\section{Locus of Control}

According Kreitner and Kinicki (2005) Locus of control is the person personality who is defined as a person's belief in the ability to control destiny in you. Robbins, Stephen P. and Judge (2008) define the locus of control as the level of control of one's beliefs that they can determine their own destiny. Larsen and Buss (2002) argue that locus of control is a basic concept that believes that occur in individuals life. According to Robbins, Stephen P. and Judge (2008: 178) suggest the definition of locus of control is as a person's view of the causes of success or failure on doing business over what he did.

According to Rotter (1966) there are various factors that affect the locus of control, namely: Internal locus of control has the meaning of individual controls from within themselves take action to determine the success of decision-making over the causes and effects that will occur in events experienced by individuals. The external locus of control means the control of an individual from outside a self-control measure to determine the success of decision-making over causes and effects that depend on the conditions of natural factors, wonders, and the environment in which the individual is situated.

Chinen and Endo (2012) revealed that if there are individuals who are able to perform good financial decision-making it is unlikely to have financial difficulties in the future and it is that the ideal financial behavior is able to determine the priority scale of needs is more important than the desire.

From some definition of locus of control according to some experts above, it can be concluded locus of control is a belief of a person realted to ability to control themselves against a view of events that happened on the basis of control factors in self by choosing the scale of priority needs and external control factors then take action to determine the failure or success. According to Ida and Dwinta (2010) there are five indicators to measure locus of control namely: There is absolutely no way to solve the problem, I am driven by life around me, there is little I can do to change the important things in My life, I can do whatever is in my mind, what happens to me in the future depends on me, helpless in facing life problem, I have little control over things that happened to me.

\section{Financial Management Behavior}

According to Jodi Lynne Mcfarlane Parrotta (1992) revealed that the behavior of personal financial management can be described as a learning process in planning, taking action in accordance with the 
planning, and make improvements to the implementation of planning that needs to be addressed in individuals or families.

According Sina and Noya (2012) one of the efforts in shaping the character of financial behavior is by growing the behavior of personal financial management by implementing financial planning and self-control of money.

From several definitions of financial management behavior according to some experts above, it can be concluded that someone with a good financial management behavior is more likely to be able to familiarize in the preparation of financial planning, implement planning by controlling yourself, evaluating the initial planning action that is not in accordance with the conditions has occurred and carried out the improvement of financial problems, and always monitor the condition of the improvement of financial problems. According to Ida and Dwinta (2010) there are five indicators for measuring financial management behavior: Controlling spending, paying my bills on time, preparing plans for my future finances, providing for myself and my family, saving money.

\section{Effect of Income on Financial Management Behavior}

Ida and Dwinta (2010) in his study stated that income does not have a relationship to financial management behavior due to the difference that income with own hard work will be more appreciate in the financial expenditure is different from the income earned from others as obtained from the family especially the parents .

This is similar to the findings of Kholilah and Iramani (2013) states that income is not related to the financial behavior of a person due to the possible lack of limiting research on married or unmarried individuals later in order to get the classification of responsibilities of spending on the basis of social status will be different.

Andrew and Linawati (2014) stated the relationship that one of the demographic factors of income can affect the behavior of individual financial management because the higher income of a person then more wiser in behaving towards the use of finance than someone who has lower incomes.

From the results of several findings above can be concluded that a person tends to be able to manage income when having high income wisely in using finance due to high income is able to allocate money to other financial activities such as spending on daily needs, education costs, saving, registering insurance, and investing so that individuals are able to manage their finances well.

\section{The Influence of Higher Education Learning to Financial Management Behavior}

In the research of Anita and Sari (2015) found that the role of college learning proved to have a positive relationship to financial management behaviour means that the more individuals follow high learning courses, especially on improved financial knowledge, the better the student's financial behavior.

Herawati (2015) stated that the contribution of college learning has proven to have no relationship to the financial management behavior, because the teaching of subjects related to financial management includes the calculation of financial analysis of the company but not detailed on the teaching of personal financial management.

From the results of some of the above findings can be concluded that at the time individuals receive learning in college more given the learning about the company's financial analysis so it will be difficult to apply into the financial management behavior due to lack of focus on teaching about personal financial management behavior. Then it should be higher education that provides learning 
INTERNATIONAL JOURNAL OF ACADEMIC RESEARCH IN BUSINESS AND SOCIAL SCIENCES

Vol. 8, No. 8, August 2018, E-ISSN: 2222-6990 @ 2018 HRMARS

of financial management is improved so that students are able to implement the learning of financial management well.

\section{The Effect of Financial Knowledge on Financial Management Behavior}

Thi et al. (2015) states that financial knowledge has a positive relationship to financial management behavior due to the role of education with the existence of seminars that more and more about financial knowledge will improve one's insight into financial management behavior.

Listiani (2017) stated in her findings that financial knowledge does not have a significant relationship meaning that someone already has financial knowledge but does not run a good financial management behavior.

Herdjiono, Damanik, and Musamus (2016) concluded that financial knowledge is not closely related to financial management behavior because there are several other factors that affect financial management behavior.

From the results of several findings above can be concluded that a person will be able to understand the financial knowledge that will be applied to the financial management behavior is influenced by formal education pursued while at school, lectures, seminars on finance or additional tutoring so as to apply in daily life day-to-day impact on good financial management behavior.

\section{Effect of Financial Literacy on Financial Management Behavior}

In the discovery of Sabri and Falahati (2012) stated that financial literacy has a relationship to financial management behaviour means that there are things that can affect that is the experience of financial expenditure, the role of the family became the main focus in financial education, and create awareness in the home about the importance of in achieving the welfare of life.

There are research findings from Borden et al. (2008) after attending a seminar on financial literacy; students reported an increase in restricting the use of credit cards in order to manage finances in a more useful way. While the results of Nidar and Bestari (2012) study that the financial literacy of students tend to be in the low category because in answering questionnaires referring to Chen and Volpe (1998) the average able to answer correctly questions about income and expenditure differ in debt category, savings, investments, insurance, personal finance the majority of the results cannot answer the question correctly it will relate that insufficient financial literacy of a person will adversely affect financial decision-making. So it needs to be increased the main focus on understanding in the field of investment, saving habits, credit, insured interest.

From the results of some findings above can be concluded individuals while doing the financial expenditure can be influenced from the learning of family finance education, through seminars on finance so as to create and foster harmony aware of the welfare of life about finance will be better in the behavior of financial management with low financial literacy it will adversely affect financial decision-making.

\section{Influence of Financial Attitude on Financial Management Behavior}

Anthony et al. (2011) states that the financial attitude has a negative relationship to financial management behavior meaning that someone has a good financial attitude but cannot keep up with the implementation so as to find a failure in financial management.

According to Listiani (2017) found that the financial attitude has a positive relationship to financial management behavior meaning that the more individuals able to perform the application of a good 
INTERNATIONAL JOURNAL OF ACADEMIC RESEARCH IN BUSINESS AND SOCIAL SCIENCES

Vol. 8, No. 8, August 2018, E-ISSN: 2222-6990 @ 2018 HRMARS

financial attitude then have a good effect on personal financial management this is due to the ideal financial attitude derived from the quality of education of a person good and able to apply to everyday life.

Maharani (2016) reveals the results of her research of financial attitude there is no relationship that affects financial management behavior because the expression of the respondents considered that the financial attitude is not required in the application of financial management wisely with the reason that there is no desire to achieve the purpose of making the plan in the short time to the future.

From the results of several findings above can be concluded that the determinant of the success of financial management behavior is good that is to get a financial education in the family and able to implement the financial attitude by being able to hold themselves to the financial owned in everyday life consistently so that will not have difficulty good financial management.

\section{The Influence of Locus Of Control on Financial Management Behavior}

Research Ida and Dwinta (2010) stated that the locus of control has no relation to financial management behavior due to lack of focus of target on research object by using locus of control should be more detailed to internal locus of control.

According to Thi et al. (2015) argues that the locus of control has a negative relationship to financial management behavior, meaning that someone who has good locus of control tends not to apply good financial management behavior in life.

According to Listiani (2017) the better the locus of control a person the better the financial management behavior pattern is also caused by internal locus of control is better because the individuals who still earn income from others (the parents) then the individual will be more careful, and appreciate the money it has, and seek to control its expenditure in accordance with the needs so as not to run out of money in every month and can be said that the locus of control there is a positive relationship to financial management behavior.

From the results of several findings above can be concluded that all individuals have a selfcontrol over the financial expenditure but the most effective self-control to be applied is the control of the inner self because within itself more able to protect all the disturbances that arise in the result of encouragement external factors and capable in determining financial decision making based on priority needs scale is more important than desire.

\section{Research Methods}

This research used a conclusive research concept that is causal. Sugiyono (2010: 8) support the type of conclusive research causality that research method used is quantitative research that has the function of researching on the population or sample that has been determined, collecting data by involving research instruments, with data quantitative / can be described by analysis graph, which aims to get the ones that have been selected as needed.

This study aims to find evidence that there is an influence of independent variables such as income, college learning, financial knowledge, financial literacy, financial attitude, locus of control on the dependent variable of financial management behavior. Source of data to be obtained this research amounted to 264 answers from respondents with measurements to fill out a questionnaire directly given to the students to get answers to the statements and questions that have been proposed. 
INTERNATIONAL JOURNAL OF ACADEMIC RESEARCH IN BUSINESS AND SOCIAL SCIENCES

Vol. 8, No. 8, August 2018, E-ISSN: 2222-6990 @ 2018 HRMARS

\section{Result}

Data retrieval in this study using a questionnaire method that returned as a whole that is as many as 264 questionnaires. The following descriptions of each respondent's characteristics are based on education, age, gender, status, and working period.

Table 2. Respondent Characteristics Based on Income

\begin{tabular}{|c|l|c|c|}
\hline No & \multicolumn{1}{|c|}{ Income } & Frequency & $\%$ \\
\hline 1 & $\leq \operatorname{Rp~1.000.000~}$ & 172 & 65,2 \\
\hline 2 & $\operatorname{Rp~1.000.000-Rp~3.000.000~}$ & 80 & 30,3 \\
\hline 3 & $\operatorname{Rp~3.000.000-Rp~5.000.000~}$ & 6 & 2,3 \\
\hline 4 & $\geq \operatorname{Rp~5.000.000~}$ & 6 & 2,3 \\
\hline \multicolumn{2}{|l|}{ Total } & 264 & 100 \\
\hline
\end{tabular}

Based on table 2. the characteristics of respondents based on income obtained the result that the majority of students have income $\leq \mathrm{Rp} 1,000,000$ as much as 172 or $60 \%$.

Table 3.Respondent Characteristics on semester

\begin{tabular}{|c|l|c|l|}
\hline No & Education & Frequenty & $\%$ \\
\hline 1 & 3 to 4th semester & 45 & 17 \\
\hline 2 & 5 to 6th semester & 90 & 34,1 \\
\hline 3 & 7 to 8 th semester & 128 & 48,5 \\
\hline 4 & $\geq 8^{\text {th }}$ semester & 1 & 0,4 \\
\hline \multicolumn{2}{|l|}{ Total } & 264 & 100 \\
\hline
\end{tabular}

Based on table 3. the characteristics of respondents based on semester obtained the result that the majority of students are in semester 7 to semester 8 as much as 128 or $48.5 \%$.

\section{Hypothesis Test Results F Statistics.}

Based on the F statistical test table, it can be stated that the significance value of 0.000 is less than 0.05 on the basis of decision making is having a significance level of $5 \%$ or 0.05 . Then the regression model can be used as a predictor of financial management behavior, or it can be said that income, college learning, financial knowledge, financial attitude, and locus of control influence simultaneously to financial management behavior.

\section{Hypothesis Test Result t Statistics}

Based on statistical test $t$, the influence of income, college learning, financial knowledge, financial literacy, financial attitude, and locus of control as follows:

The value of income significance of 0.007 is smaller than 0.05 and $t$ arithmetic of 2.739 it can be concluded that income affects the financial management behavior. This result is in accordance with the research hypothesis, where income is expected to affect financial management behavior.

The significance value of college learning amounted to 0.434 greater than 0.05 and $t$ arithmetic of 0.874 it can be concluded that college learning has no effect on financial management behavior. This result is not in accordance with the research hypothesis, where college learning is suspected to affect financial management behavior.

The value of financial knowledge significance of 0.491 is greater than 0.05 and $t$ arithmetic of 
INTERNATIONAL JOURNAL OF ACADEMIC RESEARCH IN BUSINESS AND SOCIAL SCIENCES

Vol. 8, No. 8, August 2018, E-ISSN: 2222-6990 @ 2018 HRMARS

0.690 it can be concluded that financial knowledge has no effect on financial management behavior. This result is not in accordance with the research hypothesis, where financial knowledge is expected to affect financial management behavior.

Financial literacy significance value of 0.000 smaller than 0.05 and $t$ arithmetic of 5.797 it can be concluded that the financial literacy effect on financial management behavior. This result is in accordance with the research hypothesis, where financial literacy is suspected to affect financial management behavior.

The value of financial attitude significance of 0.029 is smaller than 0.05 and $t$ arithmetic of 2.202 it can be concluded that the financial attitude has an effect on financial management behavior. This result is in accordance with the research hypothesis, where the financial attitude is expected to affect financial management behavior.

Locus of control significance value of 0.970 is greater than 0.05 and $t$ arithmetic of 0.037 it can be concluded that the locus of control has no effect on financial management behavior. This result is not in accordance with the research hypothesis, where locus of control is suspected to affect financial management behavior.

\section{Multiple linear regressions}

Based on the results of multiple linear regression in this study can be obtained a model of multiple linear regression equation as follows:

$Y=0.164+0.183$ Revenue + 0,561 Financial Literacy + 0.227 Financial Attitude + ei

\section{Coefficient of Determination}

Based on the coefficient of determination can be seen that the value of Adjusted R Square of 0.195. This shows that the independent variable is able to explain $19.5 \%$. Against the dependent variable, while $80.5 \%$ is explained by other variables outside independent variables in this study such as social environment by socializing with people around, advice from parents, and habit factors (Herdjiono et al., 2016)

\section{Influence of Revenue on Financial Management Behavior}

Based on the results of calculations by looking at $t$ test results, it can be seen that income variables affect the financial management behavior. The results are in accordance with the underlying Planned Behavior Theory (TPB) a person behaves that is by having income due to the income of someone who underlies each individual in making decisions about the use of finance. This is because the amount of income at least owned by individuals greatly affect in financial management because there are 3 financial motives that is the need, speculation, and investment. With that matter, the little amount of income owned by someone will affect in managing the finance as evidenced by the student's income tends to vary with the amount $\leq \mathrm{Rp} 1,000,000$ amounted to 172 people (65.2\%), income $\mathrm{Rp}$ $1,000,000-\leq 3,000$. 000 amounted to 80 people (30.3\%), income Rp 3,000,000 - $\leq$ Rp 5.000.000 amounted to 6 people (2.3\%), and income $\geq$ Rp5.000.000 amounted to 6 people. The higher the income of a person, the better is also in allocating everyday needs due to having a high income individuals will not have difficulty in performing financial expenses such as investing in education, saving and insurance. 
INTERNATIONAL JOURNAL OF ACADEMIC RESEARCH IN BUSINESS AND SOCIAL SCIENCES

Vol. 8, No. 8, August 2018, E-ISSN: 2222-6990 @ 2018 HRMARS

\section{The Influence of Higher Education Learning to Financial Management Behavior}

In Planned Behavior Theory (TPB) in terms of self-control behavior in a person's education will not affect financial management behavior because of the behavior experienced by individuals who refer to a trust that is believed that the ability of each individual as the basis for doing such behavior.

However, this result is in accordance with the theory of TPB in terms of attitude that is as a material evaluation of things to be done by individuals against certain behaviors. Environmental factors become one of the students get knowledge about finance by way of discussion with peers, older people.

The other factors associated with technological developments also impact on the ease of access to information for all circles and can easily read knowledge about finance that can be accessed via the internet. It includes information on finance such as investment, financial management, insurance, and loan saving. With the ease of this can also improve the behavior of financial management of students without having to follow directly learning in the classroom with various reasons including sickness permit, skipping college, and there family events that is evidenced by the various levels of student education such as students with semesters 3 to 4 amounted to 45 (17\%), students with semesters 5 to 6 were 90 people (34.1\%), students with 7 to 8 semesters were 128 people (48.5\%), students $\geq$ semester 8 amounted to 1 person $(0.4 \%)$ the level of student education does not affect the behavior of financial management. This is due to the behavior of financial management is a need to be done on every individual regardless of the level of higher education or lower education because basically every individual has the same responsibility associated with basic needs for survival. Therefore, whether each person is educated or not he will still manage the finances in the hope that will not experience financial problems in the future.

\section{The Effect of Financial Knowledge on Financial Management Behavior}

In the test of descriptive analysis, the influence of financial knowledge factor on the students of Faculty of Economics included in the category pretty knows. This indicates that the students know about financial knowledge especially the financial discussion of the company / institution and banking has an important role in the behavior of personal financial management as evidenced by the respondent's answer on item statement X3.1 "The terms interest rate, financial burden, and credit in corporate finance and banking "average able to answer" pretty know "with a value of 3.68, the item statement X3.2" Every piece has a credit note to be paid "the average able to answer pretty know with a value of 3.69, the item statement X3 .3 "Companies and banks record annual financial records" on average able to answer "many know" with a value of 4.33, on item statement X3.4 "The ability of the company / bank to pay debts to be one of" the average able answered "pretty know" with 4.02, on the statement item X3.5 "The term investment stock" on average able to answer "pretty know" with the value of 3.98, on the item statement X3.6 "Bond investment term" average able to answer quite know with the value 3.52, the item statement X3.7 "The term invest as deposits" on average able to answer "pretty know" with a value of 3.62, on the item statement X3.8 "Companies / banks have financial debt have a note of repayment" on average able to answer "pretty know" with 4.01 value.

Based on the calculation of $t$ test results, it can be seen that the variable of financial knowledge has no effect on financial management behavior. Thus, any individual who has a small amount of financial knowledge; especially the discussion of corporate finance / institution and banking does not affect the financial management behavior. 
INTERNATIONAL JOURNAL OF ACADEMIC RESEARCH IN BUSINESS AND SOCIAL SCIENCES

Vol. 8, No. 8, August 2018, E-ISSN: 2222-6990 @ 2018 HRMARS

In Planned Behavior Theory (TPB) in terms of information obtained through daily lectures do not give effect because the information obtained from teaching in the lecture is more likely to explain about the financial analysis of companies / institutions and banks, so as not to give a more detailed understanding to personal financial management behavior. However, these results are appropriate in terms of behavior control that underlies how individuals behave or make decisions to manage finances. This is because every individual has the freedom to choose everything according to their own behavior. Although financial knowledge can affect in terms of mind, but each individual still has control over himself.

\section{The Effect of High Financial Literacy on Financial Management Behavior}

In the descriptive analysis test, the influence of financial literacy factor on the students of the Faculty of Economics in the category agreed. This shows that students agree with the understanding of financial literacy especially on personal finance has an important role in the behavior of financial management. Based on the calculation of $t$ test results, it can be seen that the variables of financial literacy affect the financial management behavior.

This is in accordance with Planned Behavior Theory (TPB) in terms of information obtained through the social environment, family education, the experience of others in the use of finance, socialization, workshops, talk shows, seminars on financial literacy to give effect because by following various events such as socialization, workshops, talk shows, seminars on the financial literacy of each individual will increase knowledge about the importance of the application of financial literacy in everyday life this is evidenced by the respondent answer in the statement X4.1.1 "I always buy goods that give discounts" the average majority of respondents answered "agree" with a value of 3.74, in the statement X4.1.2 "I always buy goods that are cheap" the average majority of respondents answered "agree" with a value of 3.49, the statement X4.1.4 "I allocate 10\% of my income (parent / income from my work) to savings "on average the majority of respondents answered" agree "with a value of 3.87, in the statement X4.1.5" I am saving for a wake-up motif that can be used at any time "the average majority of respondents answered" very agree "with a value of 4.28 , in the statement X4.1.6" I save for my future goals "the average majority of respondents answered" strongly agree "to the value of 4.26 , in the statement X4.1.10" I allocate a portion of income parents ") for my educational investment" the average majority of respondents answered "agree" with a value of 3.50, in the statement X4.1.11 "I always choose quality in educational investment" the average majority of respondents answered "agree" with a value of 3,87 , in the statement X4.1.12 "I invest for profit" the average majority of respondents answered "agree" with a value of 3.81. But in terms of behavior control that underlies how each individual in behaving or taking decisions to manage finances. This is because every individual has the freedom to determine everything according to their own behavior but also to have their own control.

\section{Level Literacy Finance Students Faculty of Economics}

Based on the results of achievement level of financial literacy Students Faculty of Economics on personal finance / consuming dimension has $72.92 \%$, savings / loan dimension has $32.95 \%$, insurance dimension has $57.95 \%$ result, investment dimension $44.32 \%$ and if the calculation is accumulated by categorizing the level of financial literacy according to Chen and Volpe (1998) by summing up the correct answers and then divided the number of questions then multiplied hundred percent then the results of the financial literacy level of the Faculty of Economics of $56.21 \%$ in the low category. 
INTERNATIONAL JOURNAL OF ACADEMIC RESEARCH IN BUSINESS AND SOCIAL SCIENCES

Vol. 8, No. 8, August 2018, E-ISSN: 2222-6990 @ 2018 HRMARS

This is because respondents answered the average questionnaire was able to choose the correct answer from the dimension of personal finance / consumption while choosing the wrong answer from the dimensions of savings / loans, insurance, and investment the majority cannot answer the question correctly. So it can be concluded that the level of financial literacy Student Faculty of Economics amounted to $56.21 \%$ in the low category

\section{The Influence of High Financial Attitude to Financial Management Behavior}

In the descriptive analysis test, the influence of financial attitude factor on the students of Faculty of Economic included in the category strongly agrees. This shows that students strongly agree with the financial attitude that each individual has an important role in the behavior of financial management.

Based on the calculation of $t$ test results, it can be seen that the variable of financial attitude has an effect on financial management behavior. This is in accordance with the Planned Behavior Theory (TPB) from a subjective aspect that refers to how the individual condition experiences social pressure when having money so that confusion will be used for what with the money with this ability to hold back when having money to influence students to manage their finances. Thus, any individual who is able or unable to hold back when having money will affect the behavior of financial management, the higher one is able to refrain from the money owned then the higher the behavior of financial management as evidenced by the respondent's answer in the statement X5.1 "Important for me to develop a saving pattern and stick to it. "The average majority of respondents responded" strongly agree "to the value of 4.39 , in the statement X5.2" I should write a financial goal that helps me define spending a priority "the average majority of respondents answered "Strongly agree" with a value of 4.27, in the statement X5.3 "Every individual must be responsible for his own financial wellbeing" the average majority of respondents answered "strongly agree" with a value of 4.45 , in the statement X5.4 "I have to really concentrate when managing my finances "on average the majority of respondents answered "strongly agree" to the value of 4.29 , in the statement X5.5 "Planning the expenditure of money is very important to manage my life successfully" the average majority of respondents answered "strongly agree" with a value of 4.42, in the statement X5.6 "Planning for the future is the best way to obtain a living welfare" on average the majority of respondents answered "strongly agree" with a value of 4.46 . This is because the ability of self-restraint against money in each individual to be the beginning of the formation of attitudes to be more careful and not shuffling before making financial expenditure decisions, so the ability to refrain from the financial expenditure used for the urgent need to get used to implement the behavior of managing money.

\section{The Influence of Locus of Control High on Financial Management Behavior}

In the decriptive analysis test, the influence of locus of control factor on students of Faculty of Economics included in the category sometimes. This shows that there are students who have good locus of control or less good in financial management behavior. Based on the calculation of $t$ test results, it can be seen that the locus of control variable has no effect on financial management behavior.

In Planned Behavior Theory (TPB) from the subjective aspect of social pressure, especially the surrounding environment or peers is not appropriate because it does not give effect to this is evidenced by the respondent's answer in the statement X6.2 "I was encouraged by life around me" the average majority of respondents answered "Rarely" with a value of 3.68, in the statement X6.4 "There is very little I can do to change the important things in my life" on average the majority of respondents answered "rarely" with a value of 3.65, in the X6 statement. 5 "I can do anything that 
already exists in my mind" on average the majority of respondents answered "rarely" with a value of 4.18. By referring the characteristics of the respondents on the income owned by students who obtained from the majority parents less than $\mathrm{Rp} 1,000,000$ / per month would be difficult in managing the finance because of the tendency of students are still patterned focus on lectures so that with the focus of college then the financial expenditures of course much allocated to the fulfillment needs college. This is because the students still have no thought in the management of personal finances to obtain the welfare of life in the future which is due to focus on the fulfillment of the needs of the lectures that are undertaken.

However, these results are appropriate in terms of individual attitudes as learning to correct certain behaviors. This is because the students who are taking the course has a focus on the completion of the lecture, but different when students who have graduated their college as soon as preparing themselves to get the welfare of life in the fulfillment of daily needs.

\section{Conclusion}

Based on the results of research and discussion, can be drawn some conclusions that there is influence between income on financial management behavior, there is no influence between the learning of universities to financial management behavior, there is no influence between financial knowledge to financial management behavior, there is influence between financial literacy to financial management behavior, level of financial literacy of Faculty of Economics UNESA students in low category, there is influence between financial attitude toward financial management behavior, There is no influence between locus of control to financial management behavior. This research became one of the reference sources of learning in detail in managing personal finances. Revenue, financial literacy, and financial attitude have an effect on financial management behavior. Therefore, it is expected that students are able to develop more in managing their finances by following positive activities such as seminars on financial literacy held by government institutions / institutions.

Based on the results of the description above, it can be stated with the following suggestions for students, this is a source of personal learning in managing personal finance. Revenue, financial literacy, and adequate financial attitudes towards financial management behavior are therefore possible to be more developed in managing finances by means of positive activities such as seminars on financial literacy carried out by government institutions / agencies.

For the government this research can be used as one of the references to express and provide socialization through seminars in improving management, improving good financial attitudes, and improving students' financial literacy and providing curricula for higher education courses with good expectations from the community especially students will be very important to get life prosperity in the future with one of the best ways to manage finances well. For more detailed research to conduct research by comparing the objects of research between universities will produce results from each university that will be studied and variables that can be used for more detailed research, such as external factors of internal factors in this research variable. This is because the independent variable is only able to explain $19.50 \%$ of the department variables, while $80.50 \%$. With other variables that can be examined by further researchers are variables such as age, residence status, peers, financial self-efficacy, intelligence, love of money, and work experience. 
INTERNATIONAL JOURNAL OF ACADEMIC RESEARCH IN BUSINESS AND SOCIAL SCIENCES

Vol. 8, No. 8, August 2018, E-ISSN: 2222-6990 @ 2018 HRMARS

\section{Corresponding Author}

Name : Nadia Asandimitra

Affiliation : Department of Management, Faculty of Economics, Universitas Negeri Surabaya

Country : Indonesia

Email : nadiaharyono@unesa.ac.id

\section{References}

Ajzen. (2005). ajzeni-2005-attitudes-personality-and-behaviour-2nd-ed-open-university-press.pdf. Ajzen, I. (1988). Attitudes, Personality and Behaviour. England: Open University Press.

Andrew, V., \& Linawati, N. (2014). Hubungan Faktor Demografi dan Pengetahuan Keuangan Dengan Perilaku Keuangan Karyawan Swasta di Surabaya. Finesta, 2(2), 35-39.

Ansong, A., \& Gyensare, M. A. (2012). Determinants of University Working-Students' Financial Literacy at the University of Cape Coast, Ghana. International Journal of Business and Management, 7(9), 126-133.

Anthony, R., Ezat, W. S., Junid, S. Al, \& Moshiri, H. (2011). Financial Management Attitude and Practice among the Medical Practitioners in Public and Private Medical Service in Malaysia. International Journal of Business and Management, 6(8), 105-113.

Asandimitra, N. and Kautsar, A. (2017). Financial Self-efficacy on Woman Entrepreneurs Success. International Journal of Academic Research in Business and Social Sciences. 7(11). 293-300

Borden, L. M., Lee, S. A., Serido, J., \& Collins, D. (2008). Changing college students' financial knowledge, attitudes, and behavior through seminar participation. Journal of Family and Economic Issues, 29(1), 23-40.

Chen dan Volpe. (1998). An analysis of personal financial literacy among college students, Financial Services Review, 7(2): 107-128.7(2), 107-128.

Chinen, K., \& Endo, H. (2012). Effects of Attitude and Background on Personal Financial Ability : A Student Survey in the United States. International Journal of Management, 29(1), 33-46.

Daft, R. L. (2010). Era Baru Manajemen. (B. 2, Ed.) (Edisi 9). Jakarta: Salemba Empat.

Depdiknas. (2003). Undang-Undang Republik Indonesia Nomor 20 Tahun 2003 Tentang Sistem Pendidikan Nasional, 1-33. Retrived March 28, 2018, from https://www.komisiinformasi.go.id/regulasi/download/id/101

Eagly, A. H. \& S. C. (1993). The psychology of attitudes. Toronto: Harcourt Brace Jovanovich College. Ferdinand, A. (2002). Structural Equation Modelling dalam Penelitian Manajemen. Semarang: FE UNDIP.

Ferdinand, A. (2014). Metode Penelitian Manajemen : Pedoman Penulisan Untuk Sripsi, Tesis, dan Disertasi Ilmu Manajemen (Edisi 5). Semarang: Badan Penerbit Universitas Diponegoro.

Garman, E. Thomas., Eckert, S. W. dan R. (1985). Personal Finance. USA: USA Houghton Mifflin Company.

Ghozali, I. (2016). Aplikasi Analisis Multivariate dengan Program IBM SPSS 23 (8th ed.). Semarang: Badan Penerbit Universitas Diponegoro.

Gregory, M. N. (2003). Teori Makro Ekonomi Terjemahan. Jakarta: PT. Gramedia Pustaka Utama.

Herawati, N. T. (2015). Kontribusi pembelajaran di perguruan tinggi dan literasi keuangan terhadap perilaku keuangan mahasiswa. Jurnal Pendidikan Dan Pengajaran, 1-3(48), 60-70.

Herdjiono, I., Damanik, L. A., \& Musamus, U. (2016). Pengaruh Financial Attitude, Financial Knowledge, Parental Income Terhadap Financial Management Behaviour. Jurnal Manajemen Teori dan Penerapan.(3), 226-241. 
INTERNATIONAL JOURNAL OF ACADEMIC RESEARCH IN BUSINESS AND SOCIAL SCIENCES

Vol. 8, No. 8, August 2018, E-ISSN: 2222-6990 @ 2018 HRMARS

Hilgert, M. a., Hogarth, J. M., \& Beverly, S. G. (2003). Household Financial Management: The Connection between Knowledge and Behavior. Federal Reserve Bulletin, 106(November 1991), 309-322.

Ida, \& Dwinta, C. Y. (2010). Pengaruh Locus of Control, Financial Knowledge, Income Terhadap Financial Management Behavior. Jurnal Bisnis Dan Akuntansi, 12(3), 131-144.

Keller, K. lane dan R. S. (1987). Effects of Quality and Quantity of Information on Decision Effectiveness. Journal of Consumer Research. Volume 14, Issue 2, 1 September 1987, Pages 200213

Keown, A. (2011). The Financial Knowledge Of Canadian. Component of Statistifics Catalouge. The Financial Knowledge Of Canadian. Component of Statistifics Catalouge., 11-8.

Kholilah, N. Al, \& Iramani, R. (2013). Studi Financial Management Behavior Pada Masyarakat Surabaya. Journal Of Business and Banking 3(1), 69-80.

Kinicki, K. dan. (2005). Perilaku Organisasi. Jakarta: Salemba Empat.

Literacy, F., Anita, D., \& Sari, D. A. (2015). Financial Literacy. Buletin Bisnis dan Manajemen. 1(2), 171189.

Lusardi, A., \& Mitchell, O. S. (2007). Financial Literacy and Retirement Planning: New Evidence from the Rand American Life Panel. SSRN Electronic Journal.

Maharani, T. N. (2016). Pengaruh Personal Financial Literacy, Financial Attitude Terhadap Financial Management Behavior Mahasiswa S1 Fakultas Ekonomi Universitas Andalas. Jurnal Media Informasi Manajemen.

Mahdzan, N. S., \& Tabiani, S. (2013). The impact of financial literacy on individual saving: An exploratory study in the malaysian context. Transformations in Business and Economics, 12(1), 41-55.

Malhotra, N. K. (2009). Riset Pemasaran: Pendekatan Terapan. (J. 1, Ed.) (Keempat). Jakarta: PT. Indeks.

Martadireja, J. S. dan T. (2008). Riset Bisnis Untuk Pengambilan Keputusan. Yogyakarta: Andi.

Mason, C., \& Wilson, R. (2000). Conceptualising financial literacy. Business School Research Series, $7(1), 1-41$.

Mukeri. (2010). Kemandirian Ekonomi Solusi untuk Kemajuan Bangsa. Retrieved from http://jurnal.unpand.ac.id/index.php/dinsain/article/viewFile/92/89

Nababan, D., \& Sadalia, I. (2012). Analisis Personal Financial Literacy Dan Financial Behavior Mahasiswa Strata I Fakultas Ekonomi Universitas Sumatera Utara. Jurnal Media Informasi Manajemen. 1-16.

Nidar, S. R., \& Bestari, S. (2012). Personal Financial Literacy Among University Students (Case Study at Padjadjaran University Students, Bandung, Indonesia). World Journal of Social Sciences, 2(4), 162-171.

Niswonger. (2006). Prinsip Prinsip Akuntansi. Edisi Kesembilanbelas. (A. dan H. G. Sirait, Ed.). Jakarta: Erlangga.

Prayogi, F. D., \& Haryono, N. A. (2017). Literasi keuangan pada masyarakat Bangkalan Madura. Eproceeding Seminar Nasional Riset Inovatif 2017 1, 579-586.

Ricciardi, V., \& Simon, H. K. (2000). What is Behavioral Finance ? Business, Education and Technology Journal, II(1), 1-9.

Robbins, Stephen P. \& Judge, T. A. (2008). Perilaku Organisasi. Jakarta: Salemba Empat.

Rotter, J. B. (1966). Generalized expectancies for internal versus external control of reinforcement. Psychological Monographs: General and Applied, 80(1), 1-28. 
INTERNATIONAL JOURNAL OF ACADEMIC RESEARCH IN BUSINESS AND SOCIAL SCIENCES

Vol. 8, No. 8, August 2018, E-ISSN: 2222-6990 @ 2018 HRMARS

Sabri, M., \& Falahati, L. (2012). Estimating a Model of Subjective Financial Well-Being among College Students. International Journal of Humanities and Social Science, 2(18), 191-199.

Sanusi, A. (2011). Metodelogi Penelitian Bisnis. Jakarta: Salemba Empat.

Sekaran, U. (2006). Metode Penelitian Bisnis. Jakarta: Salemba Empat.

Shim, S., Barber, B. L., Card, N. A., Xiao, J. J., \& Serido, J. (2010). Financial Socialization of First-year College Students: The Roles of Parents, Work, and Education. Journal of Youth and Adolescence, 39(12), 1457-1470.

Simamora, B. (2005). Analisis Multivariat Pemasaran. Jakarta: Gramedia Pustaka Utama.

Sina, P. G. (2016). Financial Contemplation (Seri 1). Guepedia. Indonesia.

Sina, P. G., \& Noya, A. (2012). Pengaruh Kecerdasan Spiritual Terhadap. Jurnal Manajemen, 11(2), 171-188.

Smith, T. a, Huang, C. L., \& Lin, B. (2009). Does Price or Income Affect Organic Choice ? Analysis of U . S . Fresh Produce Users. Journal of Agricultural and Applied Economics, 41(3), 731-744.

Sohn, S. H., Joo, S. H., Grable, J. E., Lee, S., \& Kim, M. (2012). Adolescents' financial literacy: The role of financial socialization agents, financial experiences, and money attitudes in shaping financial literacy among South Korean youth. Journal of Adolescence, 35(4), 969-980.

Somantri, A. (2006). Aplikasi Statistika Dalam Penelitian. Bandung: CV. Pustaka Ceria.

Sommer, L. (2011). The Theory Of Planned Behaviour And The Impact Of Past Behaviour. International Business \& Economics Research Journal, 10(1), 91-110.

Sugiyono. (2007). Metode Penelitian Pendidikan Pendekatan Kuantitatif, Kualitatif, dan R\&D. Bandung: Alfabeta.

Sugiyono. (2009). Metode Penelitian Pendidikan Pendekatan Kuantitatif, Kualitatif, dan R\&D. Bandung: Alfabeta.

Suroto. (2000). Strategi pembangunan dan Perencanaan Perencanaan Kesempatan Kerja. Yogyakarta: Gajah Mada Univercity.

Suseno, S. dan. (2015). Uang: Pengertian, Penciptaan, dan Peranannya dalam perekonomian. Bank Indonesia: Pusat Pendidikan dan Studi Kebanksentralan.

Tanuwidjaja, W. (2009). 8 Intisari Kecerdasan Financial (Revisi). Media Pressindo.

Thi, N., Mien, N., \& Thao, T. P. (2015). Factors Affecting Personal Financial Management Behaviors: Evidence from Vietnam. Economics, Finance and Social Sciences, 978-1.

Trianto. (2009). Mendesain Model Pembelajaran Inovatif-Progresif. Jakarta: Kencana Prenada Media Group.

Wild, J. J. (2003). Financial Accounting : Information For Decisions. (Y. S. Bachtiar, Ed.) (Edisi Kedu). Jakarta: Salemba Empat.

Yoong, F. J., See, B. L., \& Baronovich, D.-L. (2012). Financial Literacy Key to Retirement Planning in Malaysia. Journal of Management and Sustainability, 2(1), 75-86. 